\title{
Thoracobrachialis- A Cadaveric Study of a Morphological Variation of Pectoralis Major with a Novel Nomenclature and Classification of the Chondroepitrochlearis Muscle
}

\author{
Rachana Suresh ${ }^{\oplus 1}$, N Hema ${ }^{\circledR 2}$, R Srinivas ${ }^{\circledR 3}$ \\ ${ }^{1}$ Research Scholar, ESIC MC \& PGIMSR, Rajajinagar, Bangalore, India, ${ }^{2}$ Associate Professor, Department of Anatomy, ESIC MC \& PGIMSR, Rajajinagar, Bangalore, India, \\ 32nd Year M.B.B.S Student, ESIC MC \& PGIMSR, Rajajinagar, Bangalore, India.
}

\section{Abstract}

Background: Anatomical variations are not uncommon in the pectoral region but the chondroepitrochlearis muscle has been of special interest in history owing to its rarity. Chondroepitrochlearis is a muscular slip that arises from the lower ribs, the inferolateral aspect of the pectoralis major, or the aponeurosis of the external oblique muscle and crosses the axilla to insert on the medial intermuscular septum or the medial epicondyle of the humerus. Multiple variants of this muscle exist including chondroepitrochlearis, chondrofascialis, costoepitrochlearis, thoracoepicondylaris, chondrohumeralis, etcetera. The objectives is to article aims to simplify and standardize the reporting of the chondroepitrochlearis muscle by proposing a novel nomenclature and classification. In this paper, we also present and discuss a case of chondroepitrochlearis. Subjects and Methods : A prospective study was conducted from 2012 to 2020 in the Department of Anatomy, ESIC MC and PGIMSR, Rajajinagar, to identify anatomical variations in the pectoral region. Results: During routine dissection of a male cadaver, an unusual slip was found on the right side and was identified as chondroepitrochlearis. Conclusion: Since the reporting of this rare muscle has been increasing in live patients, taking into consideration the variability in the presentation of the same anatomical structure, to avoid confusion, we propose a novel, blanket nomenclature- "Thoracobrachialis". We also propose a clinically relevant classification that is based on the level of insertion of the muscle and the possible neurovascular structures involved.

Keywords: Thoracobrachialis, chondroepitrochlearis, chondroepicondylaris, pectoralis muscle variations.

Corresponding Author: N Hema, Associate Professor, Department of Anatomy, ESIC MC \& PGIMSR, Rajajinagar, Bangalore, India. E-mail: Hemanesi@gmail.com

\section{Introduction}

The pectoralis major, a large, triangular muscle present on the anterior chest wall, is a medial rotator and adductor of the upper limb. It has three heads- Clavicular, sternocostal, and abdominal, originating from the anterior surface of the medial half of the clavicle, anterior surface of the sternum, true ribs along with the costal cartilages, and the aponeurosis of the external oblique muscle respectively. Anatomical variations are not a rarity in the pectoral region. They include the absence or duplication of the muscle, deletion of one or more heads of the pectoralis major (PM), presence of accessory heads, or epigastric slips. The presence of anomalous additional muscles such as sternalis, pectoralis minimus, pectoralis Quartus, chondrocoracoid, and chondroepitrochlearis have been occasionally reported. ${ }^{[1]}$ Among these, chondroepitrochlearis has been a muscle of special interest in history owing to its rar- ity.

The chondroepitrochlearis is a muscular slip arising from the lower ribs, the inferolateral aspect of the pectoralis major, or the aponeurosis of the external oblique muscle which, after crossing the axilla, inserts on the medial intermuscular septum or medial epicondyle of the humerus. ${ }^{[2]}$ It was first described and named by Duvernoy in 1955. ${ }^{[3]}$ Since then, there have been less than fifty reports of this muscle in scientific literature, to the best of our knowledge. The prevalence of chondroepitrochlearis has been reported to be 0.5 percent by Flaherty et al in a sample size of 200 , over 20 years meanwhile a prevalence rate of $2.5 \%$ was reported by Aruna et al. ${ }^{[4,5]}$

Multiple variants of this muscle exist. Therefore, it has been described under various names by previous authors based on its proximal and distal attachments including chondroepitrochlearis, chondrofascialis, cos- 
toepitrochlearis, thoracoepicondylaris, chondrohumeralis, chondrobrachialis, costohumeralis, or chondroepicondylaris [Table 1]. ${ }^{[2,3,6-12]}$ Chondropitrochlearis orCET was most commonly encountered as a thin muscle terminating into a thin tendinous slip. We believe that the tendinous slip was too slender to have contributed to any clinically apparent compression syndromes in most of the cases that were incidentally discovered during cadaveric dissection and autopsy. However, a few cases of CET have resulted in clinical conditions including cosmetic deformities, limited upper limb range of motion, neurovascular compression, upper limb lymphatic obstruction, etc. ${ }^{[13-21]}$

Today, as more and more cases of clinical presentations are being reported due to the availability of sophisticated imaging techniques, there is a pressing need for a proper definition, nomenclature, and classification of the variants of this muscle. In this study, we intend to present a case of CET and propose a novel nomenclature and clinically relevant classification of the same.

\section{Subjects and Methods}

A prospective study was conducted from September of 2012 to January of 2020 in the Department of Anatomy, ESIC Medical College and PGIMSR, Rajajinagar. By the end of the study period, the sample included 40 cadavers irrespective of sex. In total, 80 hemithoraces, axillary cavities, and arms were methodically studied to identify any anatomical variations and anomalous muscles in the pectoral region.

\section{Results}

In September of 2018, during dissection of a 65-year-old male cadaver as per the Cunningham's Manual of Practical Anatomy, after dividing the deep fascia at the deltopectoral groove and exposing the pectoralis major muscle, an unusual muscle slip was identified on the right side. It was found to arise from the $4,5,6^{\text {th }}$ ribs and their respective costal cartilages. Although indistinct from the pectoralis major muscle at its origin, the muscle slip, now independent, appeared to pass inferiorly to the lower border of the pectoralis major muscle. On further dissection, it was found that the muscle slip traveled horizontally in the axilla and attached itself to the fascia of the biceps brachii muscle in the upper one-third of the arm. From here, it descended as a $4 \mathrm{~mm}$ thick tendinous structure, diagonally from the lateral to the medial aspect of the anterior compartment, finally inserting into the medial epicondyle. Along its course, the tendon was found to cross the median nerve and brachial artery in the middle third of the arm. The ulnar nerve was found passing posteriorly to the tendon at its insertion, however, no fibrous connections were seen between them. The blood supply and nerve supply

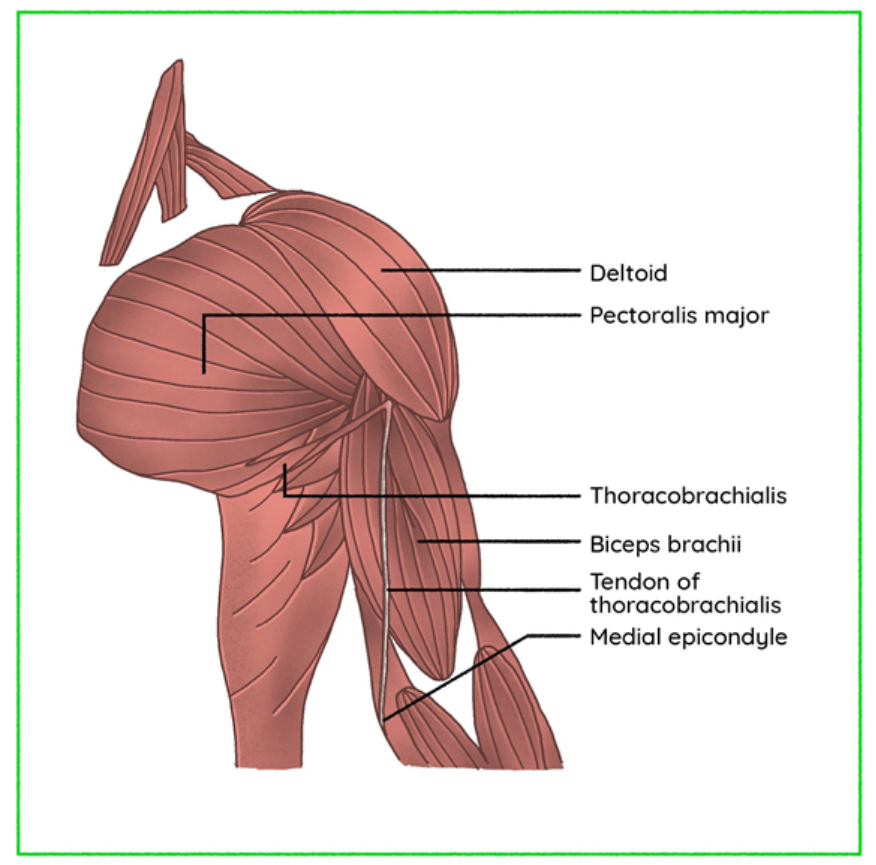

Figure 1: A s chematic representation of the specimen of Thoracobrachialis muscle.

was by the lateral thoracic artery and a branch of the medial pectoral nerve, respectively. Normal twisting of the bilaminar tendon was seen. No other muscular anomalies such as the axillary arch of Langer were noted. Subsequent dissection of the contralateral limb did not reveal any abnormality. [Figure $1-3]$

\section{Discussion}

1. Anatomy: The chondroepitrochlearis muscle, although rare, varies greatly in its presentation. It may be unilateral or bilateral. ${ }^{[4,12,22,23]}$ It may ari se as a single belly or have multiple slips. ${ }^{[2,24]}$ It may be digastric. ${ }^{[7]}$ It may arise as a fleshy muscular slip and insert into a tendon, which is the most common presentation, or originate as a slender muscular slip and proceed further to become more muscular towards its distal attachment. ${ }^{[25]}$ It may be fleshy throughout its course or remain only as a fibrous band. ${ }^{[26,27]}$ It may be only millimeters in the thickness of up to 3.8 centimeters with a reported average of $9.9 \mathrm{~mm} .{ }^{[28]}$

The muscle originated from the anterior surfaces of the ribs, costal cartilages, costochondral junctions, lateral margin of the pectoralis major muscle, external oblique aponeurosis, or deep surface of the pectoral fascia. Common insertions include the medial intermuscular septum and the medial epicondyle. Far more various are the intermediate insertions of the CET- It 


\begin{tabular}{|c|c|c|c|c|c|c|}
\hline SI. No. & Author & Presentation & Origin & Attachment & $\begin{array}{l}\text { Clinical } \\
\text { Symptoms }\end{array}$ & Management \\
\hline 1 & Fitzgerald (1936) & $\begin{array}{l}\text { Unilateral } \\
\text { (Right) }\end{array}$ & $\begin{array}{l}7^{\text {th }} \text { costal car- } \\
\text { tilage }\end{array}$ & $\begin{array}{l}\text { Medial epi- } \\
\text { condyle }\end{array}$ & $\begin{array}{l}\text { Limitation of } \\
\text { movement and } \\
\text { cosmetic }\end{array}$ & Not mentioned \\
\hline 2 & Voto et al (1987) & $\begin{array}{l}\text { Unilateral } \\
\text { (Right) }\end{array}$ & $\begin{array}{l}\text { 3-7, } 7-10 \text { carti- } \\
\text { lage (Two Ori- } \\
\text { gins) }\end{array}$ & $\begin{array}{l}\text { Medial epi- } \\
\text { condyle }\end{array}$ & $\begin{array}{l}\text { Limitation } \\
\text { fixed abduc- } \\
\text { tion and } \\
\text { cosmetic } \\
\text { deformity }\end{array}$ & $\begin{array}{l}\text { Complete resec- } \\
\text { tion }\end{array}$ \\
\hline 3 & Lin, C (1988) & & & & Contracture & \\
\hline 4 & Spinner et al(1991) & $\begin{array}{l}\text { Unilateral } \\
\text { (Right) }\end{array}$ & 6th and 7 th ribs & $\begin{array}{l}\text { Medial epi- } \\
\text { condyle, } \\
\text { brachial fascia }\end{array}$ & $\begin{array}{l}\text { Numbness of } \\
\text { fingers, axil- } \\
\text { lary pterygium }\end{array}$ & $\begin{array}{l}\text { Resection \& Neu- } \\
\text { rolysis of ulnar } \\
\text { nerve at axilla \& } \\
\text { elbow }\end{array}$ \\
\hline 5 & Di Gennaro (1998) & Bilateral & Pectoral region & $\begin{array}{l}\text { Medial epi- } \\
\text { condyle }\end{array}$ & $\begin{array}{l}\text { The func- } \\
\text { tional deficit, } \\
\text { cosmetic }\end{array}$ & $\begin{array}{l}\text { Lengthening } \\
\text { tenotomy }\end{array}$ \\
\hline 6 & Redler et al (2012) & $\begin{array}{l}\text { Unilateral } \\
\text { (Left) }\end{array}$ & $\begin{array}{l}\text { Pectoralis } \\
\text { major }\end{array}$ & $\begin{array}{l}\text { Coracobrachialis } \\
\text { fascia, brachial } \\
\text { fascia, medial } \\
\text { intermuscular } \\
\text { septum }\end{array}$ & $\begin{array}{l}\text { Shoulder pain, } \\
\text { pain with over- } \\
\text { head abduction }\end{array}$ & Resection \\
\hline 7 & $\begin{array}{l}\text { R. B. Trobs et al } \\
\text { (2015) }\end{array}$ & $\begin{array}{l}\text { Unilateral } \\
\text { (Left) }\end{array}$ & $\begin{array}{l}\text { The middle } \\
\text { part of the } \\
\text { pectoralis } \\
\text { major }\end{array}$ & $\begin{array}{l}\text { Medial epi- } \\
\text { condyle }\end{array}$ & $\begin{array}{l}\text { Impaired range } \\
\text { of motion, } \\
\text { cosmetic } \\
\text { deformity }\end{array}$ & Resection \\
\hline
\end{tabular}

may intermediately attach to the fascia covering the biceps brachii, coracobrachialis, ${ }^{[24]}$ medial head of the triceps, ${ }^{[29]}$ or into a separate fibrous cord. This fibrous cord may have an aponeurotic origin from the tendinous insertion of the pectoralis major as described by Chiba et al and Ohtani et al. It may alsooriginate from the lateral lip of the bicipital groove, in the region of the surgical neck of the humerus similar to a specimen reported by Leonard. P. Seimon, ${ }^{[8]}$ or from the greater tubercle. The latter was described and named as the "Tuberoepicondylar band" by Palagama et al. ${ }^{[12]}$

[Table 2] outlines the characteristics of previously described cases of chondroepitrochlearis demonstrating its various presentations.

The muscle described in our report was most similar to the one described by Chiba et al in which, one of the muscular slips arising from the lower ribs was found intermediately attaching to the aponeurotic sheath in the axilla, connected to the fascia overlying the short head of biceps brachii and coracobrachialis, and continuing as a long slender tendon inserting into the medial intermuscular septum and finally to the medial epicondyle. Although Landry proposed that chondroepitrochlearis must invariably be seen with an untwisted pectoralis major insertion, a good proportion of the reports in previous literature show normal twisting of the pectoralis muscle. ${ }^{[30]}$ The blood and nerve supply of our specimen was consistent with earlier reports.

2. Nomenclature: Since it was first described and named by Duvernoy in 1955 as cited by J. Wood in 1867, owing to the heterogeneity of its presentations, the nomenclature of chondroepitrochlearis muscle has been a topic of much debate and evolution.

In 1953, Leonard P. Seimon reported a very rare muscular variation arising from the anterior surfaces of the sixth rib, that resembled the earlier descriptions of CET by Perrin, Testut, and Wood. However, he opined that the then-existing terms 'Sterno chondro-epitrochlearis' or "chondro-epitrochlearis" weren't exactly appropriate for the anomalous band and tendon described by him, and proposed the name "Costoepitrochlearis". ${ }^{[8]}$

In 2005, Loukas et al, proposed the name "Thoracoepicondylaris" to accommodate the 


\begin{tabular}{|c|c|c|c|c|}
\hline Sl. No & Name & Authors & Origin & Insertion \\
\hline 1 & Pectoroepicondylaris & Sushma, KM Bhat & $\begin{array}{l}\text { A deep layer of Pec- } \\
\text { toralis major, bilami- } \\
\text { nar tendon }\end{array}$ & $\begin{array}{l}\text { The medial intermus- } \\
\text { cular septum, Medial } \\
\text { epicondyle }\end{array}$ \\
\hline 2 & Chondrofascialis & $\begin{array}{l}\text { Bergman, Barcia \& } \\
\text { Genoves, Macalister }\end{array}$ & $\begin{array}{l}\text { (L) 5th Costochondral } \\
\text { junction Costochon- } \\
\text { dral junction }\end{array}$ & $\begin{array}{l}\text { The medial fascia of } \\
\text { the arm with insertion } \\
\text { into humerus Medial } \\
\text { intermuscular septum }\end{array}$ \\
\hline 3 & Costodorsalis & Shetty et al & 6th rib & $\begin{array}{l}\text { Latissmus Dorsi mus- } \\
\text { cle }\end{array}$ \\
\hline 5 & $\begin{array}{l}\text { Chondrohumeralis/ Chondro- } \\
\text { brachialis }\end{array}$ & Lama et al & $\begin{array}{l}\text { The inferior aspect of } \\
\text { the Pectoralis major } \\
\text { close to the } 5 \text { th rib }\end{array}$ & $\begin{array}{l}\text { Fascia covering Biceps } \\
\text { brachii and the lateral } \\
\text { lip of the Intertubercu- } \\
\text { lar sulcus }\end{array}$ \\
\hline 6 & Pectoralis Quartus & Barcia \& Genoves & $\begin{array}{l}\text { Costochondral junc- } \\
\text { tion of 5th, 6th rib }\end{array}$ & $\begin{array}{l}\text { On or near the deep } \\
\text { surface of Pectoralis } \\
\text { Major }\end{array}$ \\
\hline 7 & Costohumeral & $\begin{array}{l}\text { Huxley, T Rao and } \\
\text { Prakashchandra Shetty }\end{array}$ & $\begin{array}{l}\text { 6th rib near costochon- } \\
\text { dral junction }\end{array}$ & Medial epicondyle \\
\hline 8 & Chondrocoracoid & $\begin{array}{l}\text { Macalister, Wood, Per- } \\
\text { rin }\end{array}$ & 5th costal cartilage & Coracoid process \\
\hline
\end{tabular}

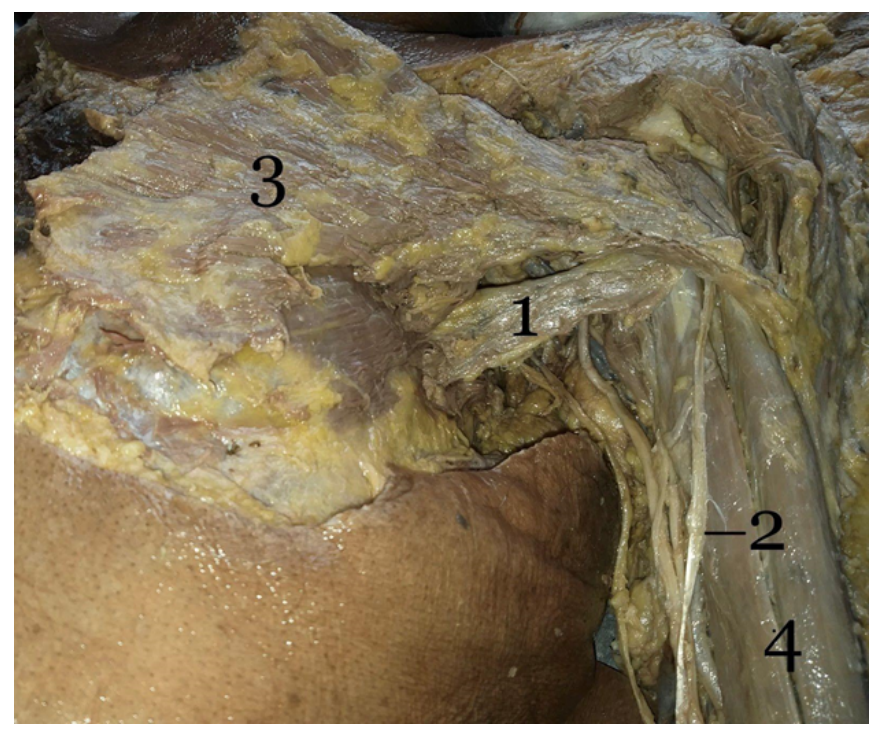

Figure 2: Photograph showing the specimen of Thoracobrachialis muscle: (1) Thoracobrachialis; (2) Tendon of Thoracobrachialis; (3) Pectoralis Major; (4) Biceps brachii ;

different origins of the muscle including the pectoralis major, external oblique, latissimus

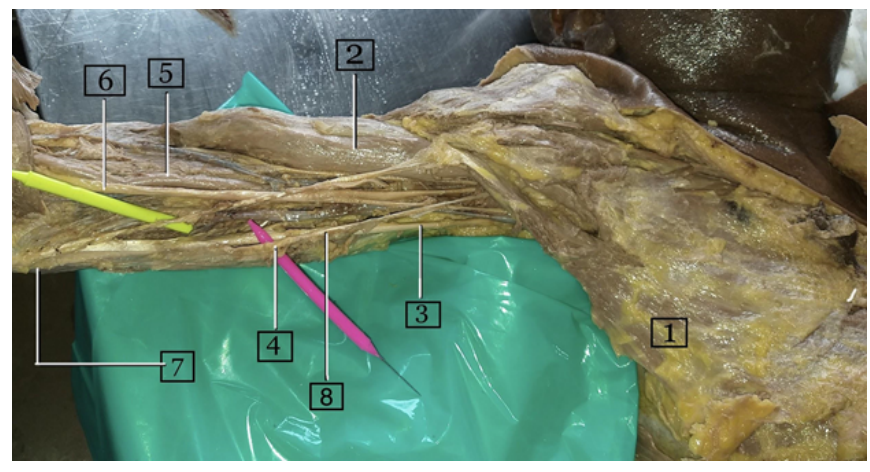

Figure 3: Photograph showing the specimen of Thoracobrachialis muscle and relevant anatomy. (1) Thoracobrachialis; (2) Biceps brachii; (3) Ulnar nerve; (4) Medial intermuscular septum; (5) Brachial artery; (6) Median nerve; (7) Medial epicondyle; (8) Medial cutaneous nerve of the forearm.

dorsi, and costal cartilages. This term also took into consideration the most common insertion, as per their review of literature- the medial epicondyle. ${ }^{[9]}$

In 2016, Palagama et al contended that almost all the specimens of CET that had been described to date had arisen, in one way or another, from the costal cartilage of the lower ribs and suggested that the name "chondroepicondylaris". ${ }^{[12]}$ 
Table 3: Previous reports of Chondroepitrochlearis/ Thoracobrachialis.

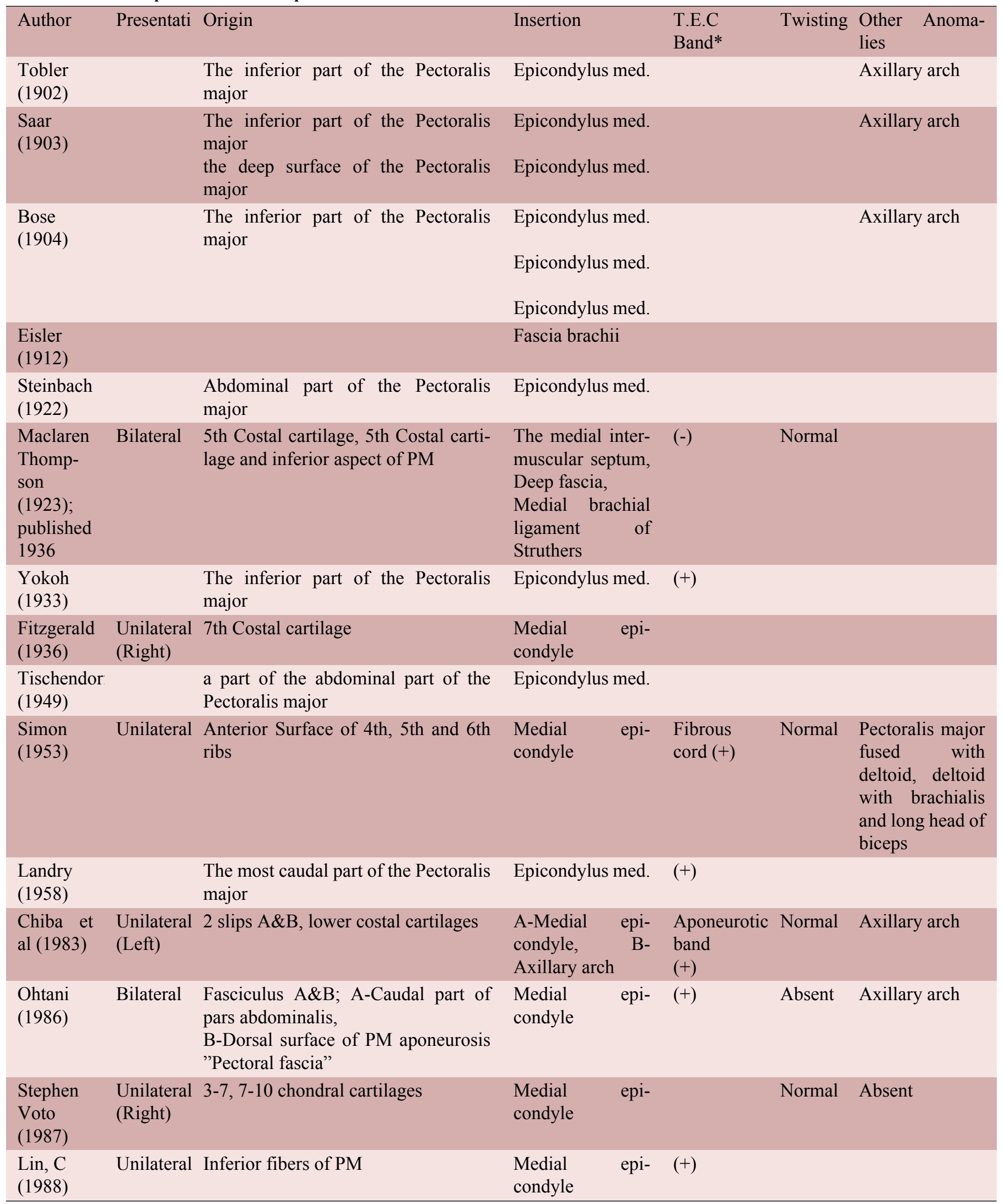




\begin{tabular}{|c|c|c|c|c|c|c|}
\hline Author & Presentation & Origin & Insertion & $\begin{array}{l}\text { T.E.C } \\
\text { Band* }\end{array}$ & Twisting & $\begin{array}{l}\text { Other } \\
\text { Anomalies }\end{array}$ \\
\hline Spinner (1991) & $\begin{array}{l}\text { Unilateral } \\
\text { (Right) }\end{array}$ & 6th, 7 th ribs & $\begin{array}{l}\text { Brachial fascia and Medial } \\
\text { epicondyle }\end{array}$ & & Normal & $\begin{array}{l}\text { Thin axillary } \\
\text { muscle arch, } \\
\text { dual nerve } \\
\text { supply }\end{array}$ \\
\hline $\begin{array}{ll}\mathrm{Di} & \text { Gennaro } \\
(1988) & \end{array}$ & Bilateral & Pectoral region & Medial epicondyle & & & \\
\hline $\begin{array}{l}\text { Sarikcioglu } \\
(2004)\end{array}$ & $\begin{array}{l}\text { Unilateral } \\
\text { (Left) }\end{array}$ & $\begin{array}{l}\text { Costochondral } \\
\text { junction of } 5 \text { th } \\
\text { and } 6 \text { th cartilages }\end{array}$ & Medial epicondyle & & Normal & $\begin{array}{l}\text { abnormal } \\
\text { insertions of } \\
\text { Pectoralis } \\
\text { major }\end{array}$ \\
\hline Loukas (2005) & $\begin{array}{l}\text { Unilateral } \\
\text { (Right) }\end{array}$ & $\begin{array}{l}\text { Lateral aspect } \\
\text { of the Pectoralis } \\
\text { major }\end{array}$ & $\begin{array}{l}\text { Medial epicondyle, Medial } \\
\text { intermuscular septum }\end{array}$ & & Normal & \\
\hline $\begin{array}{l}\text { Jaijesh } \\
(2005)\end{array}$ & Unilateral & $\begin{array}{l}\text { 6th Costal car- } \\
\text { tilage near the } \\
\text { Costochondral } \\
\text { junction }\end{array}$ & $\begin{array}{l}\text { Medial epicondyle, Medial } \\
\text { head of Triceps }\end{array}$ & & Normal & \\
\hline $\begin{array}{l}\text { Samuel and Vol- } \\
\text { lala (2008) }\end{array}$ & $\begin{array}{l}\text { Unilateral } \\
\text { (Left) }\end{array}$ & $\begin{array}{l}\text { The lower border } \\
\text { of Pectoralis } \\
\text { major on side }\end{array}$ & $\begin{array}{l}\text { The medial intermuscular } \\
\text { septum, Medial epicondyle }\end{array}$ & & Absent & No \\
\hline $\begin{array}{l}\text { Jorge. M. Barcia } \\
\text { (2009) }\end{array}$ & & $\begin{array}{l}{ }^{\circledR} \text { 5th Costochon- } \\
\text { dral junction }\end{array}$ & Medial epicondyle & & Normal & Chondrofascial \\
\hline $\begin{array}{l}\text { S. Aruna et al } \\
(2011)\end{array}$ & Bilateral & $\begin{array}{l}\text { Lower costal } \\
\text { fibers }\end{array}$ & $\begin{array}{l}\text { The medial intermuscular } \\
\text { septum, Medial epicondyle }\end{array}$ & & Absent & \\
\hline
\end{tabular}

Rare as they may be, the record of documented reports of this muscle has been growing. Most of the reports have been incidental findings during cadaveric dissection and post mortem, yet a few in vivo cases have been reported by Fitzgerald in 1936, Voto in 1987, Spinner in 1991, and JeanPaul Belgrado et al in 2016. Describing precise attachments of the muscle is possible during dissection and post mortem, but ascertaining the origins and insertions with precision may prove to be difficult with physical examination in the clinical setting or with the available imaging techniques. Even during surgical interventions for the same, which include partial or complete resection, or on occasion, just simple division of the muscle through minimal access, an extension of the surgical field to expose both the attachments may be considered superfluous. K. Natsis et al declared that during axillary lymphadenectomy, the CET appeared as a muscular bundle that appeared to arise from or near the lateral margin of the pectoralis major and appeared to insert distal to the insertion of the pectoralis major and that the variations described in the literature regarding the distal attachment did not change the appearance of the muscle during axillary lymphadenectomy. ${ }^{[21]}$ Thus, with neither the means to describe the muscle variant in patients with precision nor the need for the same, in this article, we propose a novel, blanket nomenclature for this muscular variation"Thoracobrachialis". Taking into consideration the variability in the presentation of the same anatomical structure, to avoid confusion, we think that it is prudent to forego specificity for the sake of inclusivity.

This name seems more appropriate when compared with the current definition of the CET, which indicates an origin from cartilage and insertion above the trochlea of the humerus.

Even the other nomenclatures such as 'Thoracoepicondylaris' or 'Chondroepicondylaris' are not accurate as they fail to indicate its sometimes-multiple sites of insertion.

3. Phylogeny: In earlier literature, several authors have alluded to the phylogenesis of the Chondroepitrochlearis muscle. Perrin suggested this muscular variation was reminiscent of the extensor plicae alaris of the bird. ${ }^{[31]}$ Landry rejected this theory as the "tensores patagii" or extensor plicae of birds are innervated by fibers from the posterior divisions of the brachial plexus and are thus part of the dorsal muscle mass while CET was innervated by the ventral divisions of the brachial 


\begin{tabular}{|c|c|c|c|c|c|c|}
\hline Author & Presentation & Origin & Insertion & $\begin{array}{l}\text { T.E.C } \\
\text { Band* }\end{array}$ & Twistin: & Other Anomalies \\
\hline $\begin{array}{l}\text { Redler et al } \\
(2012)\end{array}$ & $\begin{array}{l}\text { Unilateral } \\
\text { (Left) }\end{array}$ & $\begin{array}{l}\text { Origin from Pectoralis } \\
\text { major }\end{array}$ & $\begin{array}{l}\text { Intermediate } \\
\text { insertion: } \\
\text { Coraco- } \\
\text { brachialis, } \\
\text { Brachial fas- } \\
\text { cia, } \\
\text { Medial inter- } \\
\text { muscular } \\
\text { septum }\end{array}$ & & Normal & $\begin{array}{l}\text { Axillary neurovascu- } \\
\text { lar bundle deep to the } \\
\text { anomalous muscle }\end{array}$ \\
\hline $\begin{array}{l}\text { Alexander } \\
\text { Iliev } \\
(2013)\end{array}$ & $\begin{array}{l}\text { Unilateral } \\
\text { (Left) }\end{array}$ & $\begin{array}{l}\text { The lower border of the } \\
\text { Pectoralis Major near its } \\
\text { insertion }\end{array}$ & $\begin{array}{l}\text { Medial epi- } \\
\text { condyle }\end{array}$ & $\begin{array}{l}\text { Aponeurotic } \\
\text { band }(+)\end{array}$ & Normal & \\
\hline $\begin{array}{l}\text { R. B. Trobs } \\
(2015)\end{array}$ & $\begin{array}{l}\text { Unilateral } \\
\text { (Left) }\end{array}$ & $\begin{array}{l}\text { The middle part of Pec- } \\
\text { toralis Major }\end{array}$ & $\begin{array}{l}\text { Medial epi- } \\
\text { condyle }\end{array}$ & & Normal & \\
\hline $\begin{array}{l}\text { Jean-Paul } \\
\text { Belgrado } \\
(2016)\end{array}$ & $\begin{array}{l}\text { Unilateral } \\
\text { (Right) }\end{array}$ & (B) & & & & \\
\hline $\begin{array}{l}\text { Palagama } \\
(2016)\end{array}$ & Bilateral & $\begin{array}{l}\text { Costochondral junction of } \\
5 \text { th rib }\end{array}$ & $\begin{array}{l}\text { Medial epi- } \\
\text { condyle }\end{array}$ & $(+)$ & Absent & $\begin{array}{l}\text { Axillary fascial sling } \\
\text { was present, no } \\
\text { Axillary arch. }\end{array}$ \\
\hline $\begin{array}{l}\text { Tonguon } \\
\text { Kim } \\
(2018)\end{array}$ & $\begin{array}{l}\text { Unilateral } \\
\text { (Right) }\end{array}$ & $\begin{array}{l}\text { The inferolateral margin } \\
\text { of Pectoralis major }\end{array}$ & $\begin{array}{l}\text { Medial epi- } \\
\text { condyle }\end{array}$ & & Normal & Absent \\
\hline $\begin{array}{l}\text { M. A. Car- } \\
\text { roll et al } \\
(2019)\end{array}$ & Bilateral & $\begin{array}{l}\text { From the Pectoralis major } \\
\text { near the lateral insertion of } \\
\text { intertubercular } \\
\text { groove }\end{array}$ & $\begin{array}{l}\text { The medial } \\
\text { intermuscu- } \\
\text { lar septum, } \\
\text { Medial epi- } \\
\text { condyle }\end{array}$ & & Normal & $\begin{array}{l}\text { 3rd head of Biceps } \\
\text { brachii }\end{array}$ \\
\hline $\begin{array}{l}\text { Sani Bainai } \\
\text { (2019) }\end{array}$ & $\begin{array}{l}\text { Unilateral } \\
\text { (Left) }\end{array}$ & $\begin{array}{l}\text { The lower border of Pec- } \\
\text { toralis major on the side, } \\
\text { External obliques, Costo- } \\
\text { chondral junctions }\end{array}$ & $\begin{array}{l}\text { The medial } \\
\text { intermuscu- } \\
\text { lar septum, } \\
\text { Medial epi- } \\
\text { condyle }\end{array}$ & $\begin{array}{l}\text { Aponeurotic } \\
\text { band }(+)\end{array}$ & Absent & Absent \\
\hline Padavinangar & $\begin{array}{l}\text { Unilateral } \\
\text { (Left) }\end{array}$ & $\begin{array}{l}\text { The lower border of the } \\
\text { Pectoralis Major near its } \\
\text { insertion }\end{array}$ & $\begin{array}{l}\text { Medial epi- } \\
\text { condyle }\end{array}$ & & & $\begin{array}{l}\text { Muscle became more } \\
\text { muscular \& tendinous } \\
\text { towards its insertion }\end{array}$ \\
\hline
\end{tabular}

*TEC band- Tuberoepicondylar band.

plexus as it was a derivative of the pectoralis major. He also disagreed with Ruge's claim that the CET was homologous to the Panniculus carnosus of mammals since the insertion of CET was into a bony landmark instead of the undersurface of the skin. He concluded that the CET was merely an atavistic anomaly that suggested the distal insertion of the pectoralis major in quadrupeds. ${ }^{[30]}$ This is the most widely accepted theory to this date.

3. Classification and clinical anatomy: Superior to the insertion of the coracobrachialis, which is in the middle of the medial surface of the humerus, the neurovascular bundle of the arm consists of the brachial artery, the basilic, and brachial veins and the median, radial, ulnar and medial cutaneous nerve of the forearm. The radial nerve leaves the bundle first, to the sulcus for the radial nerve on the posterior surface of the humerus. The ulnar nerve is next to leave the bundle at the middle of the arm, through the medial intermuscular septum into the posterior compartment. Below this, the basilic vein and the medial cutaneous nerve of the forearm pass into the superficial fascia. Thus, in the lower third of the arm, the 


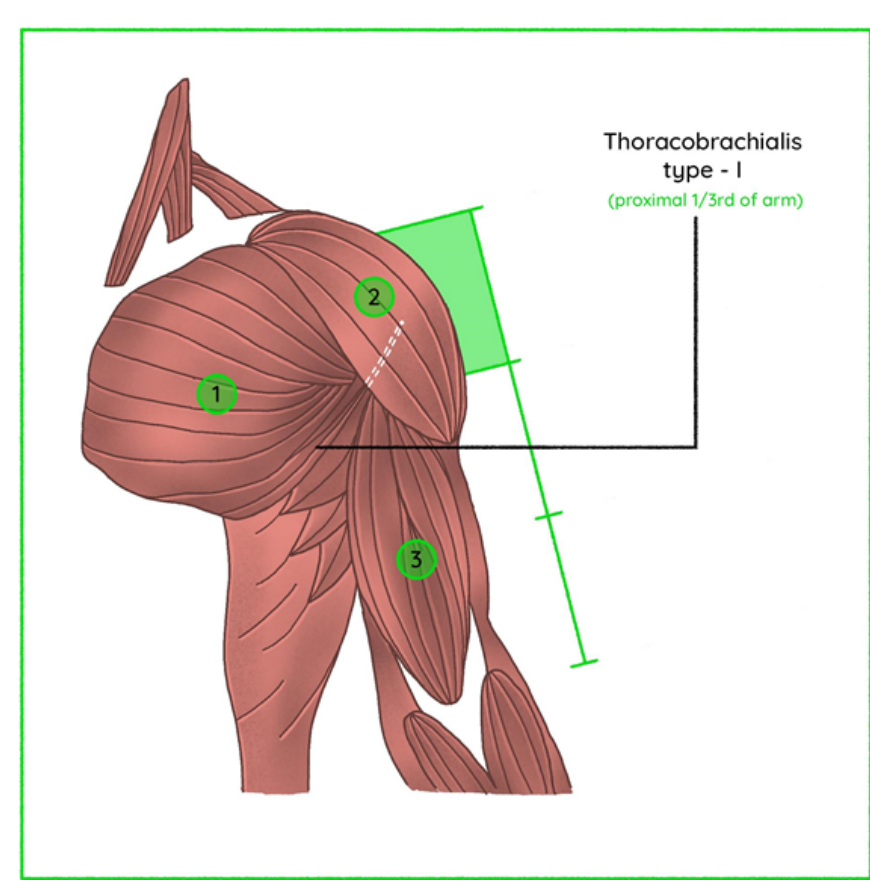

Figure 4: A schematic representation of the specimen of Thoracobrachialis type I muscle: (1) Pectoralis Major; (2) Deltoid; (3)Biceps brachii.

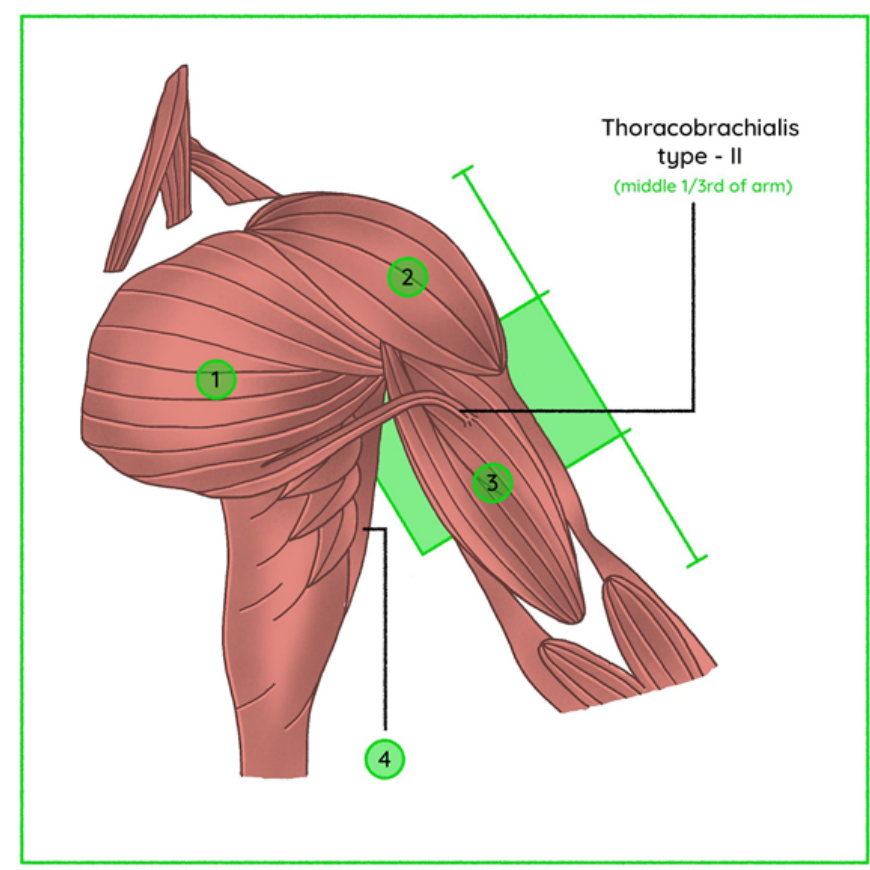

Figure 5: A schematic representation of the specimen of Thoracobrachialis type II muscle: (1) Pectoralis major; (2) Deltoid; (3)Biceps brachii; (4) Lattisimus dorsi.

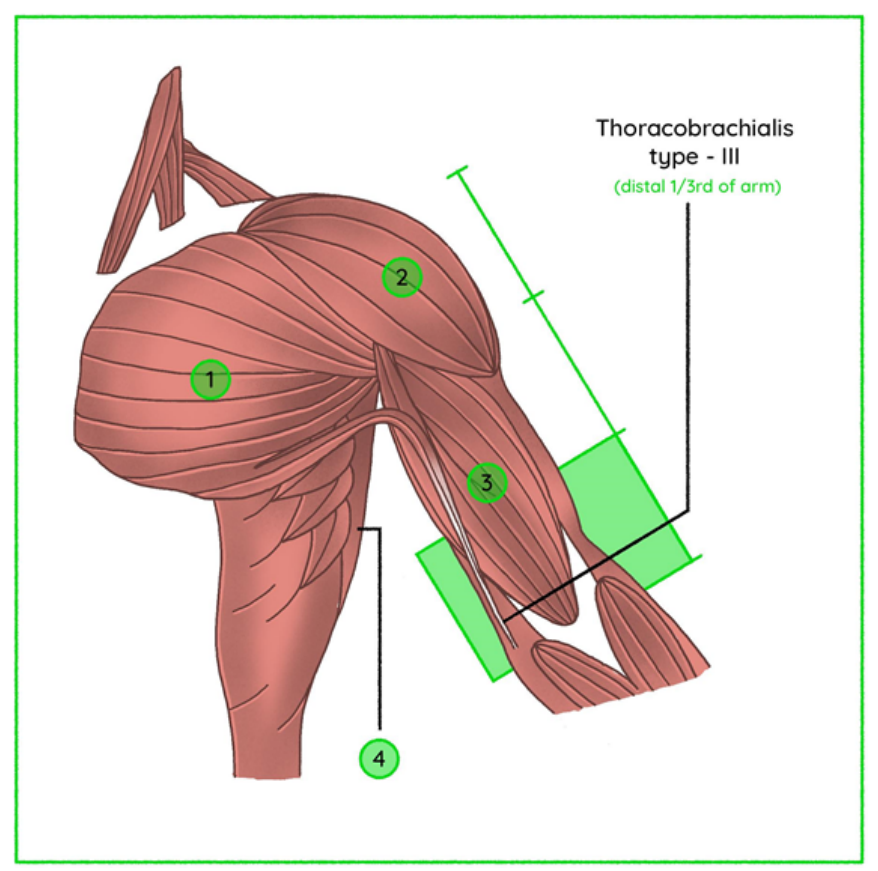

Figure 6: A schematic representation of the specimen of Thoracobrachialis type III muscle: (1) Pectoralis major; (2) Deltoid; (3) Biceps brachii; (4) Lattisimus dorsi.

neurovascular bundle only contains the median nerve and the brachial artery and veins. The ulnar nerve runs behind the medial epicondyle before entering the cubital tunnel. ${ }^{[32]}$

The clinical symptoms produced by the compression of the neurovasculature can be localized with respect to the above anatomy. Therefore, we propose a novel classification of the Thoracobrachialis muscles, to suggest the extent and insertion as well as the most common neurovascular structures involved. We recommend the use of the nomenclature

"Thoracobrachialis" when the muscle is widely inserted along the length of the arm or has multiple ill-defined points of insertion. When the level of insertion (not the exact point of insertion, which may be difficult to define in a live patient) can be sufficiently ascertained, the following classification may be employed as an adjunct to the name "Thoracobrachialis". The group under which currently defined variants may be classified will be included thereunder. The classification would include types I, II, III, and IV and is as follows.

- Thoracobrachialis type I- Insertion of the variant muscular slip or the tendon thereof, into the proximal one-third of the arm. [Figure 4] The slip may be inserted separately into the lateral lip of the intertubercular sulcus, to the fascia covering the biceps brachii muscle/coracobrachialis muscle or may merge into the latissimus dorsi muscle. The variants of CET that may be included in this category 
include chondrohumeralis, ${ }^{[10]}$ chondrofascialis, and pectoralis Quartus muscle. ${ }^{[6,7]}$ Barcia and Genoves suggested that the chondrofascialis may be an intermediate form between the pectoralis Quartus and chondroepitrochlearis muscle. This category may also include complex presentations including a case with the presence of both axillary arches of Langer and CET in which, both the muscular variants are inserted at a common site into the fascia covering the biceps brachii. ${ }^{[10]}$ Axillary vessels, lymphatics, and nerves may be involved causing intermittent compression of the axillary vein, thrombosis and upper limb lymphedema. ${ }^{[20]}$

- Thoracobrachialis type II- Insertion of the variant muscular slip or its tendon into the middle one-third of the arm. [Figure 5] The common points of insertion may include the intermuscular septum, fascia over the biceps brachii muscle, and coracobrachialis muscle. The variants to be defined under this category may include chondrofascialis. As the musculotendinous structure of thoracobrachialis/CET crosses the median nerve and brachial vessels from lateral to the medial side, it may compress and cause entrapment of the same. The structure may also cross the ulnar nerve before it leaves the neurovascular bundle to the posterior compartment. Ulnar nerve entrapment here may result in a condition similar to Cubital tunnel syndrome. ${ }^{[16]}$

- Thoracobrachialis type III- Insertion of the variant muscular slip or its tendon into the distal one-thirds of the arm. [Figure 6] This is the most common region of insertion of the thoracobrachialis/ CET muscle and includes the medial intermuscular septum and medial epicondyle. It may cross the median nerve and brachial vessels and cause entrapment symptoms similar to the median nerve and brachial artery compression seen by a supracondylar ridge and ligament of Struthers. Here, the CET was also found to be closely related to the ulnar nerve on several occasions. It may cause ulnar nerve entrapment close to the medial epicondyle mimicking cubital tunnel syndrome. ${ }^{[16]}$

- Thoracobrachialis type IV- This would include the outliers of the definition of thoracobrachialis such as the pectoroepicondylaris muscle. ${ }^{[33]}$ It may also include remnant forms of the CET that are localized only to the arm. ${ }^{[2,27]}$

5. Clinical presentation: Most cases of Chondroepitrochlearis present as slender musculotendinous units and do not cause any functional deficits and are liable only to incidental detection. To the best of our knowledge, the first clinical presentation of Chondroepitrochlearis was reported by Fitzgerald in 1936, in a one-year-old male child, with a fibrous band extending from the chest to his right arm, forming a web-like structure in the axilla on the right side. This abnormal muscle is likely to present with an axillary pterygium constituting a cosmetic deformity. ${ }^{[13-20]}$ The CET is functionally an adductor and has, in all reports of its presence, resulting in an impaired range of motion of the arm includ- ing fixed limited abduction. CET also was reported to cause pain on overhead abduction and weakness. It is susceptible to forming contractures. ${ }^{[15]}$

Chondroepitrochlearis, if present in the surgical field during procedures such as axillary lymphadenectomy, impedes the approach and removal of the axillary contents. ${ }^{[21]}$ It may cause a lymphatic obstruction and upper limb lymphedema and interfere with other surgeries in the axilla such as sentinel lymph node biopsy, lymph node transfer, lymphovenous anastomosis, etc.

Perhaps, the more baleful consequence of the CET is the neurovascular compression. Structures compressed by the muscle belly, tendon, or the tuberoepicondylar band may vary depending on the level as elaborated in earlier sections. A summary of clinical presentations currently available in literature has been tabulated in [Table 3].

\section{Conclusion:}

Due to its anatomical location, the awareness of this muscular variant is pertinent to both anatomists and surgeons. To summarize-

- It should be considered in the differential diagnoses of conditions such as thrombosis of upper limb vessels, lymphedema, and nerve entrapment syndromes.

- When present, this anatomical aberration may pose challenges to certain surgeries including lymph node resection and lymph node transfers.

- When required, the thoracobrachialis is an easily expendable donor for tendon transfers.

We suspect that the rarity of this muscle may be attributed to the reporting of different variations of the same muscle under different names. It is the purpose of this article to simplify and standardize the reporting of this muscle.

\section{Acknowledgment}

We thank the entire staff of the Department of Anatomy, ESIC MC \& PGIMSR, Rajajinagar for encouraging us to carry out this study. The authors are also grateful to Mr. Anand Rajan for his fine work on the illustrations.

\section{References}

1. Palagama SPW, Tedman RA, Barton MJ, Forwood MR. Bilateral Chondroepitrochlearis Muscle: Case Report, Phylogenetic Analysis, and Clinical Significance. Anat Res Int. 2016;2016:5402081. Available from: https://dx.doi.org/10. 1155/2016/5402081.

2. Bergman RA, Thompson SA, Afifi AK, Saadeh FA; 1998. 
3. Wood J. Variations in human myology observed during the winter session of 1866-67 at King's College, London. Royal Society of London;p. 1867-1867.

4. FLAHERTY G, O'NEILL MN, FOLAN-CURRAN J. Case report: bilateral occurrence of a chondroepitrochlearis muscle. Journal of Anatomy. 1999;194(2):313-315. Available from: https://dx.doi.org/10.1046/j.1469-7580.1999.19420313. x. doi:10.1046/j.1469-7580.1999.19420313.x.

5. Aruna S, Rajila R, Vaithianathan G. Bilateral Chondroepitrochlearis Muscle: Incidence, Phylogenetic and Clinical Significance. J Clin Diagn Res. 2011;5(1):31-34.

6. Barcia JM, Genovés JM. Chondrofascialis versus pectoralis quartus. Clinical Anatomy. 2009;22(8):871-872. Available from: https://dx.doi.org/10.1002/ca.20798. doi:10.1002/ca.20798.

7. M A, M. On muscular anomalies in human anatomy, and their bearing upon homotypical myology, statistics on the musculature. Proc R Irish Acad. 1866;10:121-164.

8. Seimon LP. MUSCULUS COSTO-EPITROCHLEARIS. AN UNUSUAL PECTORAL MUSCLE ANOMALY IN A SOUTH AFRICAN NEGRO. Journal of Pediatric Orthopaedics. 1988;8(1):123-123. Available from: https://dx.doi.org/10.1097/01241398-198801000-00061. doi:10.1097/01241398-198801000-00061.

9. Loukas M, Louis RG, Kwiatkowska M. Chondroepitrochlearis muscle, a case report and a suggested revision of the current nomenclature. Surgical and Radiologic Anatomy. 2005;27(4):354-356. Available from: https://dx.doi.org/10. 1007/s00276-005-0337-4. doi:10.1007/s00276-005-0337-4.

10. Polly L, P BK. Chondrohumeralis and axillary arch of langer: a rare combination of variant muscles with unique insertion. Romanian Journal of Morphology and Embryology. 2010;51(2):395-397.

11. Rao T, Shetty P, Rao S. Additional slip of pectoralis major muscle-the costohumeralis. IJAV. 2009;2:35-37.

12. Palagama SPW, Tedman RA, Barton MJ, Forwood MR. Bilateral Chondroepitrochlearis Muscle: Case Report, Phylogenetic Analysis, and Clinical Significance. Anatomy Research International. 2016;2016:1-8. Available from: https://dx.doi.org/10. 1155/2016/5402081. doi:10.1155/2016/5402081.

13. Fitzgerald RR. A case showing the chondro-epitrochlearis muscle. J Anat. 1936;70:273-274.

14. Voto SJ, Weiner DS. The Chondroepitrochlearis Muscle. J Pediatr Orthop. 1987;7(2):213-214. Available from: https: //dx.doi.org/10.1097/01241398-198703000-00021.

15. Lin C. Contracture of the chondroepitrochlearis and the axillary arch muscles. A case report. J Bone Joint Surg Am. 1988;70(9):1404-1406.

16. Spinner RJ, Carmichael SW, Spinner M. Infraclavicular Ulnar Nerve Entrapment Due to a Chondroepitrochlearis Muscle. J Hand Surg. 1991;16(3):315-317. Available from: https://dx. doi.org/10.1016/0266-7681(91)90060-2.

17. Gennaro GLD, Soncini G, Andrisano A, Valdiserri L. The chondroepitrochlearis muscle: case report. Chir Organ Mov. 1998;4(83):419-423.
18. Tang P, Ahmad C, Kim H, Redler L. An anomalous accesory pectoralis major muscle: a case report. Am J Sports Med. 2012;40(9):2149-2153. Available from: https://doi.org/10. $1177 / 0363546512454659$.

19. Tröbs RB, Gharavi B, Neid M, Cernaianu G. Chondroepitrochlearis Muscle - A Phylogenetic Remnant with Clinical Importance. Klin Padiatr. 2014;227(04):243-246. Available from: https://dx.doi.org/10.1055/s-0034-1395553.

20. Thomet C, Belgrado JP, Vankerckove S, Grijseels S, Heijmans $\mathrm{S}$, Sinet SD, et al. The chondroepitrochlearis muscle: A rare cause of axillary vein thrombosis and lymphedema. Lymphol. 2016;49:133-139.

21. Natsis K, Vlasis K, Totlis T, Paraskevas G, Noussios G, Skandalakis $\mathrm{P}$, et al. Abnormal muscles that may affect axillary lymphadenectomy: surgical anatomy. Breast Cancer Res Treat . 2010;120(1):77-82. Available from: https://dx.doi.org/10. 1007/s10549-009-0374-5.

22. Thompson IM;

23. OHTANI O, KIKUTA A, TAGUCHI T, OHTSUKA A, MURAKAMI T. Case Report. The Chondro-epitrochlearis, an Aberrant Slip of the Pectoralis Major. Okajimas Folia Anat Jpn. 1986;63(2-3):127-132. Available from: https://dx.doi.org/10. 2535/ofaj1936.63.2-3_127.

24. CHIBA S, SUZUKI T, KASAI T. A Rare Anomaly of the Pectoralis Major ? the Chondroepitrochlearis. Okajimas Folia Anat Jpn. 1983;60(2-3):175-185. Available from: https://dx. doi.org/10.2535/ofaj1936.60.2-3_175.

25. Padavinangadi A, Kumar N, Rao MK, Nayak SB. Unilateral Existence of Chondro-epitrochlearis: Its Embryological Perspectives and Clinical Implications. J Clin Diagn Res. 2016;10(7):1-2. Available from: https://dx.doi.org/10.7860/ JCDR/2016/18352.8103.

26. Bryce T. Note on a group of varieties of the pectoral sheet of muscle. J Anat Physiol . 1899;34(1):75-78.

27. Iliev A, Jelev L, Kartelov Y, Malinova L, Hinova-Palova D, Paloff A. Unusual fibrous band in the brachium-a probable remnant from the rare chondroepitrochlearis muscle. Scripta Sci Med. 2013;45(1):115-117.

28. Carroll MA, Lebron EM, Jensen TE, Cooperman TJ. Chondroepitrochlearis and a supernumerary head of the biceps brachii. Anat Sci Int. 2019;94(4):330-334. Available from: https://dx.doi.org/10.1007/s12565-019-00483-5.

29. Jaijesh P. Unilateral appearance of a chondro-epitrochlearis muscle-a case report. Indian J Plast Surg. 2005;38(2):164-164. Available from: https://dx.doi.org/10.4103/0970-0358.19791.

30. Jr L. The phylogenetic significance of the chondroepitrochlearis muscle and its accompanying pectoral abnormalities. J Anat. 1958;92(1):57-61.

31. Perrin J. Notes on some variations of the pectoralis major, with its associated muscles. J Anat Physiol. 1871;5(2):233-420.

32. Romanes GJ. The arm. In:Cunningham's Manual of Practical Anatomy. United States: Oxford University Press; 1986.

33. Kotian SR, Bhat KM. Pectoro-epicondylaris: a rare extension of the pectoralis major muscle. Rev Arg Anat Clin. 2013;5:2932. 
Copyright: (C) the author(s), 2020. It is an open-access article distributed under the terms of the Creative Commons Attribution License (CC BY 4.0), which permits authors to retain ownership of the copyright for their content, and allow anyone to download, reuse, reprint, modify, distribute and/or copy the content as long as the original authors and source are cited.

How to cite this article: Suresh R, Hema N, Srinivas R. Thoracobrachialis- A Cadaveric Study of a Morphological Variation of Pectoralis Major with a Novel Nomenclature and Classification of the Chondroepitrochlearis Muscle. Acad. Anat. Int. 2020;6(2):1-11.

DOI: dx.doi.org/10.21276/aanat.2020.6.2.1

Source of Support: Nil, Conflict of Interest: None declared. 